\title{
Workaholism in IT: An Analysis of the Influence Factors
}

\author{
Octavian Dospinescu ${ }^{1, * \mathbb{C}}$ and Nicoleta Dospinescu ${ }^{2}$ \\ 1 Department of Accounting, Business Information Systems and Statistics, Faculty of Economics and Business \\ Administration, Alexandru Ioan Cuza University, 700506 Iasi, Romania \\ 2 Department of Management, Marketing and Business Administration, Faculty of Economics and Business \\ Administration, Alexandru Ioan Cuza University, 700506 Iasi, Romania; dnicole@uaic.ro \\ * Correspondence: doctav@uaic.ro
}

Received: 25 October 2020; Accepted: 17 November 2020; Published: 26 November 2020

check for updates

\begin{abstract}
The purpose of this article is to make an exhaustive analysis of the influencing factors for the phenomenon of workaholism in IT. In contemporary economies, workaholism is an increasingly common phenomenon. Companies should evaluate the impact on workers of this trend, and note that knowledge of the factors influencing the decision to overwork can be a competitive advantage when implementing human resources policies. Our approach involved the use of multivariate analysis of variance combined with multiple linear regression analysis. The article analyzes the data from 178 respondents who are employed in the IT sector in Romania, taking into account seven potential factors of influence. The data and econometric analyses were processed in IBM SPSS Software. The results of the multivariate analysis of variance combined with multiple linear regression analysis show a significant relationship between workaholism and influencing factors such as the remunerative component of work, the intrinsic pleasure of working, the sense of responsibility towards family, and the desire to develop during a professional career. In this study, socio-demographic influences were found to have a weak influence on the decision to work excessively.
\end{abstract}

Keywords: workaholism; influence factors of workaholism; IT industry; workaholism in IT

\section{Introduction}

Workaholism is a reality for contemporary society in most fields of activity. However, Clark et al. (2016) explain that the scientific research on the phenomenon is still currently at an early stage because, at present, there is not yet an agreement in terms of defining the gaze and measuring the adequacy of the phenomenon; however, their study showed that workaholism is not related to demographic issues such as gender, marital status, or parental status. Recent research (Molino et al. 2016) has shown that the trend of working in excess is significantly correlated with negative outcomes in three important areas of life: health, family, and employment. So far, this view has also been confirmed by Clark et al. (2016), whose results provide evidence that overwork and workaholism generate negative results at an individual, interpersonal, and organizational level.

Advanced research in the field of psychology (Aziz and Burke 2015) has shown that behavioral aspects related to a person's appetite for hard work include stable individual traits or predispositions. In addition to individual predispositions, situational factors also play an important role in encouraging development of the workaholism syndrome. In a similar context, Stoeber and Damian (2016) show that at the employee level, the workaholism syndrome manifests itself in three approaches related to work: work engagement, work in excess in the form of workaholism, and job burnout.

The results obtained by Hakanen and Peeters (2015) indicate that, beyond its suggested benefits for organizations, active involvement in work can stimulate the positive interactions between work 
and family for an individual, while workaholism can lead in time to conflicts between work and family needs. It is important for companies to make a clear distinction between a commitment to work and workaholism; the seven-year research study recommends that organizations encourage a firm commitment to work and discourage workaholism so that they can have employees with sustainable work arrangements and happy family lives.

Workaholism can have multiple causes and motivations. Clark et al. (2016) show that often, workaholism is related to one's own personality traits (perfectionism, a type A personality) that are achievement-oriented; on the other hand, workaholism has no significant connection with other personality traits such as self-esteem and conscientiousness.

Regarding the analysis of workaholism, we found that there are some studies on this issue in the literature for different domains such as agriculture, construction, consulting services (Taris et al. 2012), and the banking industry (Andreassen et al. 2012). During an analysis of a specialized bibliography on relevant research from the past 15 years, it was highlighted that no relevant analysis was conducted on the factors that determine the phenomenon of workaholism in IT companies, and only individual studies were carried out focusing on Romania (Negrila 2019; Butucescu and Uscatescu 2013; Nistor 2014) to highlight the effects of the phenomenon.

Considering the importance of the IT sector in Romania (turnover, number of employees, premises for development, number of students pursuing IT specializations) on the one hand, and the lack of research on workaholism in this field on the other hand, we consider that our research is relevant because it aims to analyze the factors influencing workaholism in the IT sector in Romania. The multiple linear regression analysis we performed highlights the factors that are determinant in the phenomenon of workaholism, as well as their levels of importance for different aspects of the phenomenon.

The research questions we answer in this scientific article are the following: what are the main factors influencing the phenomenon of workaholism in IT? What is the individual importance of each influencing factor in the overall phenomenon of workaholism in IT?

The article is organized into the following sections: the abstract, introduction, literature review, materials and methods, and results and discussions. The introduction section presents the general context of the research problem, while the literature review section presents the previous relevant research and the state of the IT industry in Romania. Then, the materials and methods section presents the research hypotheses. Finally, the results and discussions section presents the results obtained in detail, as well as the managerial implications and future directions for the research.

\section{Literature Review}

\subsection{Determinant Factors of Workaholism in the Context of the Modern Economy}

Workaholism has been analyzed in various ways and specialized studies; Taris et al. (2012) have shown that employees who are more prone to this phenomenon tend to be workers in the agricultural sector, construction, communications, consulting, and trade, as well as managers and higher-level professionals. On the other hand, public sector and social services employees do not seem to be affected by the phenomenon of workaholism. Research to date has shown that an employee's tendencies towards workaholism can be determined by assessing various individual influencing factors. Zhang et al. (2020) have shown that the need to reach personal well-being is a very strong motivating factor towards the process of being hard working. According to Van den Broeck et al. (2011), this aspect of personal well-being often affects another important component: one's own health. These aspects in turn belong to two types of motivations: controlled motivation and autonomous motivation. Controlled motivation is directly associated with compulsive work that leads to burnout at work, while self-motivation is associated with workaholism that does not generate unpleasant perceptions. In Asia, the study conducted by Sharma and Sharma (2011) showed that workaholism is significantly influenced by the size of the wage incentive. 
Research conducted by Alonderienè et al. (2017) has shown that in terms of jobs in the white-collar area in Europe (Lithuania, Germany, Switzerland), the tendency to work overtime is mainly determined by the intrinsic pleasure of working, which is determined by an accumulation of external factors. Özsoy (2019) shows that one of the factors that significantly influence the decision to work overtime is determined by the satisfaction in the marital relationship. Thus, a study conducted in Turkey reveals that there is a significant negative relationship between marital satisfaction and willingness to work excessively. On the other hand, Yuksel (2014) and Hakanen and Peeters (2015) show that working overtime can harm affective family relationships. The owners of small and medium enterprises feel much more attached to the business and usually the economic activities are carried out and managed by the family members. From this perspective, the study conducted in the United States by Wiatt and Marshall (2020) shows that men are more prone to workaholism due to the feeling of obligation to ensure and maintain the well-being of the family. Motivation to work increases with the number of dependent children in the family.

According to Zhang et al. (2020), workaholics have a very strong inner motivation and enjoy working perseveringly and with enthusiasm. They are stimulated to work to meet their need to demonstrate their own competence. Additionally, Gillet et al. (2017) and Clark et al. (2016) showed that a strong factor influencing the desire to work with increased enthusiasm is the need to demonstrate perfectionism in the workplace. This need to demonstrate one's own perfectionism to others was seen by Ryan (1982) as an obvious manifestation of the ego in order to gain self-esteem and recognition from others. van Beek et al. (2011) found that those who choose to work overtime are driven by a desire to meet certain organizational and economic standards, and the study conducted by Popescu et al. (2018) revealed that the information and communication technology industry includes creative knowledge workers. In terms of job satisfaction, Tziner et al. (2011) show that this is closely related to organizational justice.

In Europe, Andreassen et al. (2019) conducted extensive cross-sectional research in Norway on a sample of more than 1600 employees and found that duties (tasks) at work, control and role conflict, as well as negative actions have a substantial contribution to the manifestation of workaholism. As a result, workaholism is also a result of psychological pressures that are exerted on employees by the internal environment of the organization. In the same direction, Lanzo et al. (2016), Burke et al. (2004), and Kanai et al. (1996) show that workaholism is significantly associated with psychological stress in the workplace. This psychological stress is felt mainly as a result of destructive leadership, according to the study conducted by Molino et al. (2019) and is a particularly important aspect that affects the sustainability of activities at work.

According to Kim et al. (2019), the fear of losing the job is another determinant of workaholism in Asia (South Korea, China, Indonesia, Philippines); this is especially the case among foreign workers. The study conducted by Shin and Shin (2020) shows that job insecurity has positive effects on workaholism. In Europe, Andreassen et al. (2012) found that in the banking system, workaholism is often determined by the desire to climb the hierarchical scale within the organization and to occupy management positions. On the other hand, Burke and MacDermid (1999) highlighted that for employees who are already in management positions there is a negative relationship between workaholism and career satisfaction, and they start to have a tendency to quit. The research conducted by Kim et al. (2020) revealed that supervisors' workaholism is positively related to subordinates' emotional exhaustion through increased perceived workload and interpersonal conflict, which result in subordinates' turnover intention.

Starting from the existing results in the scientific literature, Table 1 shows the determinants that may have a significant influence on workaholism. 
Table 1. Factors of influence for workaholism.

\begin{tabular}{|c|c|c|}
\hline Factor of Influence & Contents & Literature Review \\
\hline Employee remuneration & $\begin{array}{c}\text { Personal well-being, earnings and } \\
\text { extra-earnings }\end{array}$ & $\begin{array}{c}\text { (Zhang et al. 2020; Sharma and Sharma 2011; } \\
\text { Van den Broeck et al. 2011) }\end{array}$ \\
\hline The intrinsic pleasure of working & Own job satisfaction & (Alonderienè et al. 2017; Zhang et al. 2020) \\
\hline $\begin{array}{l}\text { Encouragement/support from } \\
\text { one's life partner }\end{array}$ & Marriage/cohabitation relationship & (Özsoy 2019; Yuksel 2014; Hakanen and Peeters 2015) \\
\hline $\begin{array}{c}\text { Feeling of responsibility towards } \\
\text { one's family }\end{array}$ & $\begin{array}{l}\text { The need to ensure and maintain the } \\
\text { well-being of the family }\end{array}$ & (Wiatt and Marshall 2020) \\
\hline $\begin{array}{l}\text { The need to demonstrate } \\
\text { competence }\end{array}$ & $\begin{array}{c}\text { The need to demonstrate perfectionism, } \\
\text { the need to show competence, } \\
\text { self-esteem, ego satisfaction }\end{array}$ & $\begin{array}{l}\text { (Gillet et al. 2017; van Beek et al. 2011; Clark et al. 2016; } \\
\text { Ryan 1982) }\end{array}$ \\
\hline $\begin{array}{l}\text { The desire for hierarchical } \\
\text { advancement }\end{array}$ & Obtaining a top-management position & $\begin{array}{l}\text { (van Beek et al. 2011; Burke and MacDermid 1999; } \\
\text { Andreassen et al. 2012; Kim et al. 2020) }\end{array}$ \\
\hline Fear of losing the job & $\begin{array}{l}\text { Psychological stress, fear of losing the } \\
\text { job, fear of failure }\end{array}$ & $\begin{array}{c}\text { (Kim et al. 2019; Lanzo et al. 2016; Burke et al. 2004; } \\
\text { Kanai et al. 1996; Molino et al. 2019) }\end{array}$ \\
\hline
\end{tabular}

Source: authors' own processing based on the specialized literature.

\subsection{Aspects Regarding the Importance of IT Industry in Romania}

One of the most effervescent economic sectors in the world and in Romania is the IT industry. This is justified by the evolution of several representative indicators. Thus, according to Bolocan (2019), the number of IT workers increased in Romania by 33\% in 2019, reaching a total of 100,000 employees. This increase has multiple causes starting from a tradition of the education system with IT as the main field of study and reaching to fiscal facilities granted to programmers who are exempted from paying the state income tax (Oncu 2019). Additionally, according to the study conducted by Caraiman (2020), the level of income in the IT industry is significantly higher than the national average (National Statistic Institute 2019). This can be a serious impetus for new applicants to access careers in this sector of activity, on levels of competence of junior type (average salary $=870$ EUR), middle (average salary $=1720 \mathrm{EUR}$ ), senior (average salary $=2260 \mathrm{EUR}$ ).

From the point of view of the age of IT employees in Romania, the recruitment platforms (Sirbu 2019) mainly record CVs, applications, and job offers for candidates aged between 18 and 45 years.

The productivity level of the sector is also confirmed by the fact that although there are only 100,000 employees in the Romanian IT industry, their share in the gross domestic product is $6 \%$, with a growth potential of $10 \%$ in the next five years (Bolocan 2019), also contributing to entrepreneurial behavior with consequences for economic efficiency at the macroeconomic level (Nitu-Antonie et al. 2017).

According to specialized financial analyses (Dumitrescu 2019), foreign investors control $53 \%$ of the capital of software companies in Romania, while the share of domestic investors is $47 \%$. The list of the most representative IT companies operating in Romania is made up of domestic companies and subsidiaries of foreign companies operating globally: Oracle, IBM, Ericsson, Endava, NTT Data, Electronic Arts, Continental, King Games Studio, Microsoft. Foreign investors come from 60 countries, with the largest share coming from Germany, Luxembourg, the Netherlands, the United Kingdom, and Cyprus.

From the point of view of geographical distribution, the Romanian IT industry is concentrated in several economic centers: Bucharest, Cluj-Napoca, Iasi, Timisoara, Brasov. These economic centers are in fact the most representative university centers that have higher education programs in the field of information technologies (Mihai 2017). Universities have adapted and diversified in the past 10 years their study specializations (Muntean 2016; Bejinariu 2019; Danaiata et al. 2018), so that at present educational programs with IT specialization are available in the polytechnic, medical, economic, mathematical, and computer science fields of study. 


\section{Materials and Methods}

\subsection{Aims and Hypotheses}

In this article we aim to clearly define the influence and contribution of the following indicators on the phenomenon of workaholism within Romanian IT companies: (1) employee remuneration; (2) the intrinsic pleasure of working; (3) impulse/support from one's life partner; (4) the feeling of responsibility towards one's family; (5) the need to demonstrate competence; (6) desire for hierarchical advancement; (7) fear of losing the job.

The initial hypothesis is that the variables mentioned above have an important impact on workaholism regarding the employees in the IT industry. More than this, we will also test the relationship between these indicators and some representative socio-demographic variables.

Considering the specialized studies summarized in Table 1, previous studies have considered only some of these factors or small groups of influencing factors. Our research is important and relevant because it performs an exhaustive analysis of the variables with significant influence on the phenomenon of workaholism in the IT industry in Romania. Our study also classifies these indicators for the first time in the scientific literature. The result of the research consists in selecting and highlighting the indicators that have a specific level of significance. The selected indicators, starting from the previous partial results from the scientific literature, are analyzed as individual hypotheses (H1-H7), as can be seen in Table 2.

Table 2. The research hypotheses.

\begin{tabular}{cr}
\hline $\mathbf{H}$ & Alternative Hypothesis \\
\hline H1 & The employee remuneration has a significant impact on the phenomenon of workaholism in IT. \\
H2 & The intrinsic pleasure of working has a significant impact on the phenomenon of workaholism in IT. \\
H3 & The support from one's life partner has a significant impact on the phenomenon of workaholism in IT. \\
H4 & The feeling of responsibility towards one's family has a significant impact on the phenomenon of workaholism in IT. \\
H5 & The need to demonstrate competence has a significant impact on the phenomenon of workaholism in IT. \\
H6 & The desire for hierarchical advancement has a significant impact on the phenomenon of workaholism in IT. \\
H7 & The fear of losing the job has a significant impact on the phenomenon of workaholism in IT. \\
\hline
\end{tabular}

In our research, we also aim to analyze whether various demographic aspects can generate a significant impact on workaholism. Based on this additional objective, we propose the following additional hypotheses as they are detailed in Table 3.

Table 3. The additional research hypotheses.

\begin{tabular}{cc}
\hline $\mathbf{H}$ & The Hypothesis \\
\hline Ha1 & The phenomenon of workaholism depends significantly on age. \\
Ha2 & The phenomenon of workaholism depends significantly on gender. \\
Ha3 & The phenomenon of workaholism depends significantly on marital status. \\
\hline & Source: authors' own processing.
\end{tabular}

\subsection{Variables and Instruments}

In order to confirm or refute the proposed research hypotheses presented in Tables 2 and 3, the research includes several variables. Thus, the independent grouping variables are age, gender, and marital status. The independent variables are of interval type (scale of values) and they refer to the employee remuneration, the intrinsic pleasure of working, the support from one's life partner, the feeling of responsibility towards one's family, the need to demonstrate own competence, the desire for hierarchical advancement, fear of losing the job.

The phenomenon of workaholism manifested for IT workers in Romania was assessed based on a questionnaire that includes 11 questions: 4 questions consider the criteria for filtering respondents and their demographic characteristics, while 7 questions refer to independent variables that are analyzed 
in the research. Each worker was asked to rate the significance of each indicator analyzed for the phenomenon of workaholism. We used the Likert scale to rate from 1 (the factor has a very low effect) to 5 (the factor has a very strong effect) the opinion of the respondents on the decision to overwork.

\subsection{Sample}

Our study analyzed responses from 178 respondents. The sample was calibrated by using (RaoSoft 2020) for the entire population of IT workers in Romania (100,000 IT specialists). For a 95\% confidence level, the sample size must be at least 139 for a distribution of responses equal to $90 \%$. Out of the total respondents surveyed, 37.64\% were more than 25 years old (millennials) and $62.36 \%$ were less than 25 years old (generation $\mathrm{Z}$ ), $64.41 \%$ of respondents were male, and $35.59 \%$ were female. Regarding marital status, $22.59 \%$ were married and $77.41 \%$ were single.

\subsection{Statistical Analysis of Data and Procedure}

The survey was conducted in Romania between January and March 2020. The survey was distributed in electronic format to 178 workers in the IT industry in Iasi-Romania, one of the representative centers in Southeast Europe (Ciulu and Iosub 2017). The participation of the respondents was voluntary. No financial or material rewards were involved for the questionnaire respondents. The respondents were between 18 and 45 years old; age separation was achieved for two representative and recognized generations in the literature (Alonderiene et al. 2017; Agheorghiesei Corodeanu 2015): millennials and Z-generation. Descriptive statistics (mean values, deviation) were used for all data collected from respondents. The tool that we used to calculate the statistical indicators and coefficients was IBM SPSS Statistics v. 21. Based on a detailed literature review, we set the research hypotheses. The reliability of the questionnaire was analyzed using the Cronbach's Alpha test. The verification of research hypotheses was done by using several statistical analyses, in various stages: Pearson correlation (to analyze the correlation between independent variables and dependent variable), multivariate analysis of variance (to determine demographic groups and their influence on the phenomenon of workaholism), and the multiple linear regression analysis model (to determine the relevant coefficients of the multiple linear regression equation).

The reliability of the questionnaire was verified by calculating the Cronbach's Alpha coefficient. Thus, for $\mathrm{N}=7$ the value of Alpha $=0.715$ was obtained, which according to DeVellis (2003) validates the internal consistency of the survey that was used to obtain the answers from the respondents.

\section{Results and Discussion}

The values of descriptive statistics are presented in Table 4. We took into consideration all the seven independent factors selected from the scientific literature and for the dependent variable (workaholism level).

As it can be seen from Table 4, the respondents considered that the level of workaholism was mainly affected by the following variables: the fear of losing the job $(\mathrm{M}=4.64)$, the feeling of responsibility towards one's family $(\mathrm{M}=4.42)$, and intrinsic pleasure of working $(\mathrm{M}=4.21)$. According to the means of the survey's answers, the level of workaholism was less affected by the support from one's life partner $(\mathrm{M}=2.43)$, the remuneration component $(\mathrm{M}=3.91)$, and the need to demonstrate competence in work $(\mathrm{M}=4.15)$. These values partially confirm some previous research conducted in the literature on workaholism.

In order to test the validity of $\mathrm{H} 1-\mathrm{H} 7$ hypotheses, we used the analysis based on multiple linear regression. In this econometrical model, the dependent variable is the level of workaholism in the Romanian IT industry, and the independent variables are employee remuneration, intrinsic pleasure to work, support from one's life partner, the feeling of responsibility towards one's family, the need to demonstrate competence at work, the desire for hierarchical advancement, the fear of losing the job. All variables were included in the multiple linear regression model by using the Enter method; we also used linear association. Following the calculations performed using IBM SPSS Statistics, the data from 
Table 5 were obtained. The Beta column contains the coefficients with standardized values. For the elaboration and validation of the econometric model in this article, a significance threshold of less than $5 \%$ was taken into account for the values of the coefficients to be considered relevant.

Table 4. Independent and dependent variables in the IT industry-descriptive statistics.

\begin{tabular}{|c|c|c|c|c|c|c|}
\hline Indicators & Based on Previous Research & $\mathbf{N}$ & Minimum & Maximum & Mean & Standard Deviation \\
\hline Employee remuneration & $\begin{array}{l}\text { (Zhang et al. 2020; Sharma and Sharma 2011; } \\
\text { Van den Broeck et al. 2011) }\end{array}$ & 178 & 2.00 & 5.00 & 3.9101 & 0.67726 \\
\hline Intrinsic pleasure of working & (Alonderienè et al. 2017; Zhang et al. 2020) & 178 & 2.00 & 5.00 & 4.2191 & 0.53786 \\
\hline Support from one's life partner & (Özsoy 2019; Yuksel 2014; Hakanen and Peeters 2015) & 178 & 1.00 & 5.00 & 2.4326 & 1.27490 \\
\hline $\begin{array}{l}\text { The feeling of responsibility } \\
\text { towards one's family }\end{array}$ & (Wiatt and Marshall 2020) & 178 & 2.00 & 5.00 & 4.4213 & 0.59136 \\
\hline $\begin{array}{l}\text { The need to demonstrate } \\
\text { competence }\end{array}$ & $\begin{array}{l}\text { (Gillet et al. 2017; van Beek et al. 2011; } \\
\quad \text { Clark et al. 2016; Ryan 1982) }\end{array}$ & 178 & 1.00 & 5.00 & 4.1503 & 0.65167 \\
\hline $\begin{array}{l}\text { Desire for hierarchical } \\
\text { advancement }\end{array}$ & $\begin{array}{l}\text { (Burke and MacDermid 1999; van Beek et al. 2011; } \\
\text { Andreassen et al. 2012; Kim et al. 2020) }\end{array}$ & 178 & 1.00 & 5.00 & 4.1742 & 0.79405 \\
\hline Fear of losing the job & $\begin{array}{l}\text { (Kim et al. 2019; Lanzo et al. 2016; Burke et al. 2004; } \\
\text { Kanai et al. 1996; Molino et al. 2019) }\end{array}$ & 178 & 2.00 & 5.00 & 4.6404 & 0.62431 \\
\hline Workaholism & & 178 & 3.00 & 5.00 & 4.3090 & 0.61067 \\
\hline
\end{tabular}

Source: authors' own processing.

Table 5. The independent variables' impact on the description of workaholism in the IT industry.

\begin{tabular}{cccc}
\hline Indicators & Beta & T & Sig. \\
\hline (Constant) & $0.772^{*}$ & 2.097 & 0.037 \\
Employee remuneration & $0.334^{* *}$ & 5.323 & 0.000 \\
Intrinsic pleasure of working & $0.215^{*}$ & 2.522 & 0.013 \\
Support from one's life partner & 0.032 & 1.071 & 0.286 \\
The feeling of responsibility towards one's family & $0.201^{* *}$ & 2.854 & 0.005 \\
The need to demonstrate competence & -0.070 & -1.060 & 0.291 \\
Desire for hierarchical advancement & $0.150^{* *}$ & 2.935 & 0.004 \\
Fear of losing the job & 0.005 & 0.074 & 0.941 \\
\hline
\end{tabular}

Note: * Significant for the $5 \%$ level, ${ }^{* *}$ Significant for the $1 \%$ level. Source: authors' own processing.

It should be noted that, as a result of the performed calculations, the R-Square indicator has the value of 0.444 , and $\mathrm{F}=19.360, p<0.01$. Values from Table 5 lead us to conclude that workaholism is significantly statistically influenced by some of the analyzed indicators. This affirmation is also supported by the values of the multicollinearity test for independent variables (VIF = variance inflation factor) which are presented analytically in Table 6.

Table 6. Multicollinearity test (VIF) statistics.

\begin{tabular}{ccc}
\hline Indicators & Tolerance & VIF \\
\hline Employee remuneration & 0.676 & 1.480 \\
Intrinsic pleasure of working & 0.581 & 1.721 \\
Support from one's life partner & 0.843 & 1.186 \\
The feeling of responsibility towards one's family & 0.705 & 1.418 \\
The need to demonstrate competence & 0.656 & 1.523 \\
Desire for hierarchical advancement & 0.744 & 1.344 \\
Fear of losing the job & 0.607 & 1.647 \\
\hline
\end{tabular}

Source: authors' own processing.

Given that the VIF values for all the independent variables are less than 2.00 , we certainly conclude that the variables are not collinear. The result of this multicollinearity analysis is strong evidence to support the model's validity.

Based on the indicators' contribution from Table 5, we note that workaholism in the IT industry is positively determined by employee remuneration (Beta $=0.334$ ), the intrinsic pleasure of working (Beta $=0.215)$, the feeling of responsibility towards one's family (Beta $=0.201)$, and the desire for hierarchical advancement (Beta $=0.150)$. 
Based on the research conducted and the results obtained, we can conclude that the research hypotheses H1, H2, H4, and H6 are confirmed. So we can affirm that the correlations related to the variables about the employee remuneration, the intrinsic pleasure of working, the feeling of responsibility towards one's family, and the desire for hierarchical advancement are confirmed. The assumptions are not supported for indicators of support from one's life partner for workaholism, the need to demonstrate competence at work, and the fear of losing the job.

In order to test the hypotheses about the demographic variables (Ha1-Ha3), we implemented the multivariate analysis of variance. The purpose was to highlight whether the level of workaholism in terms of remunerative component, the intrinsic pleasure of working, the feeling of responsibility towards one's family, and the desire for hierarchical advancement depends on the socio-demographic factors: gender, age, and marital status.

The data and significance thresholds presented in Table 7 as a result of the performed calculations reveal the fact that only the Ha1 hypothesis is partially supported. Additionally, the hypotheses $\mathrm{Ha} 2$ and Ha3 are not supported. According to the results of the multivariate analysis of variance, the age indicator generates differences that are statistically significant for the variables remuneration component $(\mathrm{F}=3.548, p<0.10)$, intrinsic pleasure of working $(\mathrm{F}=5.747, p<0.05)$, and desire for hierarchical advancement $(\mathrm{F}=6.353, p<0.05)$. Gender generates significant differences only for the variable intrinsic pleasure of working $(\mathrm{F}=20.006, p<0.01)$. In the developed model in our research, marital status does not generate statistically significant differences for the factors included. This means that the model of the linear multiple regression equation is generally valid for all demographic categories in the IT industry.

Table 7. The demographic variables-the contribution in the prediction of dependent variables.

\begin{tabular}{cccc}
\hline & Demographic Variable/Dependent Variable & F & Sig. \\
\hline \multirow{2}{*}{ Age } & Employee remuneration & $3.548^{*}$ & 0.061 \\
& Intrinsic pleasure of working & $5.747^{* *}$ & 0.018 \\
& Support from one's life partner & 2.026 & 0.156 \\
& The feeling of responsibility towards one's family & 0.529 & 0.468 \\
The need to demonstrate competence & 1.803 & 0.181 \\
Desire for hierarchical advancement & $6.353^{* *}$ & 0.013 \\
Fear of losing the job & 2.503 & 0.115 \\
Gender & Employee remuneration & 1.652 & 0.200 \\
& Intrinsic pleasure of working & $20.006^{* * *}$ & 0.000 \\
& Support from one's life partner & 0.172 & 0.679 \\
& The feeling of responsibility towards one's family & 2.318 & 0.130 \\
The need to demonstrate competence & 0.742 & 0.390 \\
Desire for hierarchical advancement & 0.063 & 0.801 \\
& Fear of losing the job & 0.816 & 0.368 \\
& Employee remuneration & 0.211 & 0.647 \\
Marital status & Intrinsic pleasure of working & 1.302 & 0.255 \\
& Support from one's life partner & 0.966 & 0.327 \\
& The feeling of responsibility towards one's family & 0.207 & 0.650 \\
& The need to demonstrate competence & 1.763 & 0.186
\end{tabular}

Note: * Significant for the $10 \%$ level, ${ }^{* *}$ Significant for the $5 \%$ level, ${ }^{* * *}$ Significant for the $1 \%$ level. Source: authors' own processing.

Based on the analysis performed in this study, it is clear that the following factors have a significant influence on the workaholism in the IT industry: employee remuneration, the intrinsic pleasure of working, the feeling of responsibility towards one's family, and the desire to advance in the professional 
hierarchy. According to the analysis conducted in this research, the linear regression model that contains only statistically relevant variables is shown in the following equation:

$$
\mathrm{Y}=0.772+0.334 \times \mathrm{X} 1+0.215 \times \mathrm{X} 2+0.201 \times \mathrm{X} 3+0.150 \times \mathrm{X} 4
$$

where:

- $\mathrm{X} 1=$ the remunerative component;

- $\quad \mathrm{X} 2$ = the intrinsic pleasure of working;

- $\mathrm{X} 3=$ the feeling of responsibility towards the family;

- $\mathrm{X} 4=$ the desire to advance in the professional hierarchy.

The results also show that only age generates some statistically significant differences in terms of motivation for workaholism in the IT industry. The other demographic factors do not have any relevant influence.

The article is relevant because it is the first one of this kind which comprehensively addresses the factors influencing workaholism, presenting a concise and scientifically documented picture. The previous research mostly focused on individual indicators or groups of indicators, while our research provides a complex analysis of the factors influencing workaholism in the IT industry. The results of the study are useful to human resource managers in IT companies because they provide an objective and representative tool that can help identify employee motivators, possibly by including them in an existing framework (Tofan et al. 2015).

Based on the results of this article, human resources departments can assess the condition of employees by placing them in a relevant profile. Depending on the dynamics and organizational culture, companies can recruit employees whose attitude towards work is compatible with the long-term objectives of the company. If the attitude of employees towards work and their individual performance do not converge with the company's objectives, the influencing factors highlighted in this research can be a scientific benchmark in assessing the causes of the problem.

Given that the research was conducted in a country where the IT industry is very competitive, the results of the study are also an important benchmark for IT companies operating in other countries.

Regarding the limitations of the article, we note that the research results are limited to the cluster of Romanian IT companies. As we described above, we analyzed only seven variables that can influence workaholism in IT together with three socio-demographic variables. Therefore, the research is constrained by these limited numbers.

Based on the results obtained in this article, we identify several future research directions. One of these could be the analysis of workaholism in a comparative manner by including other countries or geographical regions. Another future direction could be related to the analysis of the influence on workaholism according to several relevant indicators at regional level. The inclusion of many socio-demographic factors in the comparative analysis could be a new additional research direction. Another direction for the future could be analysis performed on clusters of types of occupations in the IT industry (programmers, database administrators, network administrators, web developers, etc.).

Author Contributions: Conceptualization, O.D. and N.D.; methodology, O.D. and N.D.; software, O.D.; validation, O.D. and N.D.; formal analysis, O.D.; investigation, N.D.; resources, N.D.; data curation, N.D.; writing-original draft preparation, O.D. and N.D.; writing-review and editing, N.D. All authors have read and agreed to the published version of the manuscript.

Funding: This research received no external funding.

Conflicts of Interest: The authors declare no conflict of interest.

\section{References}

Agheorghiesei Corodeanu, Daniela-Tatiana. 2015. Consumer's protection from the generation Y's perspective. A research based on scenarios. Procedia Economics and Finance 20: 8-18. [CrossRef] 
Alonderienè, Raimonda, Juliane Fuchs, Miglè Pilkaitė, and Margarita Pilkienè. 2017. Workaholism and Individual Work Performance in Lithuanian and German Financial Sector Multinational Corporations: Differences Between Generations X and Y. In Intercultural Interactions in the Multicultural Workplace. Contributions to Management Science. Edited by Małgorzata Rozkwitalska, Łukasz Sułkowski and Slawomir Magala. Cham: Springer, pp. 205-26.

Andreassen, Cecilie Schou, Holger Ursin, Hege R. Eriksen, and Ståle Pallensen. 2012. The Relationship of Narcissism with Workaholism, Work Engagement, and Professional Position. Social Behavior and Personality 40: 881-90. [CrossRef]

Andreassen, Cecilie Schou, Morten Birkeland Nielsen, Ståle Pallesen, and Johannes Gjerstad. 2019. The relationship between psychosocial work variables and workaholism: Findings from a nationally representative survey. International Journal of Stress Management 26: 1-10. [CrossRef]

Aziz, Shahnaz, and Ronald J. Burke. 2015. Personality factors, workaholism, and heavy work investment. In Applied Psychology Series. Heavy Work Investment: Its Nature, Sources, Outcomes, and Future Directions. London: Routledge, Boca Raton: Taylor \& Francis Group, pp. 31-46.

Bejinariu, Alexa. 2019. Facultățile din România care te ajută să-ți găsești cel mai ușor un loc de muncă. Available online: https://www.vice.com/ro/article/wjvwpy/cele-mai-bune-facultati-din-romania (accessed on 8 January 2020).

Bolocan, Valentin. 2019. Numărul IT-iştilor angajaţi a crescut cu 33\% în ultimul an. Piaţa muncii are nevoie în continuare de programatori. Adevarul Newspaper. Available online: https: //adevarul.ro/news/eveniment/numarul-it-istilor-angajati-crescut-33-ultimul-an-piata-muncii-nevoiecontinuare-programatori-1_5dc1aae65163ec4271b83fa9/index.html (accessed on 6 January 2020).

Burke, Ronald J., and Graeme MacDermid. 1999. Are workaholics job satisfied and successful in their careers? Career Development International 4: 277-82. [CrossRef]

Burke, Ronald J., Astrid M Richardsen, and Monica Mortinussen. 2004. Workaholism among Norwegian managers: Work and well-being outcomes. Journal of Organizational Change Management 17: 459-70. [CrossRef]

Butucescu, Andreea, and Lavinia Uscatescu. 2013. What does the Romanian workaholic look like? A first glimpse into the links between workaholism and employee characteristics; a validation attempt of DUWAS scale. Psihologia Resurselor Umane 11: 17-32.

Caraiman, Florentina. 2020. Topul salariilor din IT. Perspective pentru 2020. Revista Cariere, January 14.

Ciulu, Ruxandra, and Lavinia Iosub. 2017. Employer Branding: Match Maker or Breaker for IT Companies in Romania? Paper presented at International Conference on European Financial Regulation, Iasi, Romania, May 18-20; Edited by Mihaela Tofan, Angela Roman and Irina Bilan. pp. 307-18.

Clark, Malissa, Jesse Michel, Ludmila Zhdanova, Shuang Pui, and Boris Baltes. 2016. All Work and No Play? A Meta-Analytic Examination of the Correlates and Outcomes of Workaholism. Journal of Management 42: 1836-73. [CrossRef]

Danaiata, Doina, Ana-Maria Negovan, and Luminita Hurbean. 2018. Accepting Information Technology Changes in Universities-A Research Framework. In Informatics in Economy. IE 2016. Lecture Notes in Business Information Processing. Edited by Gheorghe Cosmin Silaghi and Robert Buchmann. Cham: Springer.

DeVellis, Robert. 2003. Scale Development: Theory and Applications: Theory and Application. Thousand Okas: Sage. Dumitrescu, Nora. 2019. Două companii IT clujene, în top 10 România. Transilvania Business Magazine, November 8. Gillet, Nicolas, Alexandre J. S. Morin, Baptiste Cougot, and Marylène Gagné. 2017. Workaholism profiles: Associations with determinants, correlates, and outcomes. Journal of Occupational and Organizational Psychology 90: 559-86. [CrossRef]

Hakanen, Jari, and Maria Peeters. 2015. How Do Work Engagement, Workaholism, and the Work-to-Family Interface Affect Each Other? A 7-Year Follow-Up Study. Journal of Occupational and Environmental Medicine 57: 601-609. [CrossRef]

Kanai, Atsuko, Mitsuru Wakabayashi, and Sheila Fling. 1996. Workaholism among employees in Japanese corporations: An examination based on the Japanese version of the Workaholism Scales. Japanese Pshycological Research 38: 192-203. [CrossRef]

Kim, Joon-ho, Seung-hye Jung, Soo-yun Yang, and Hyun-ju Choi. 2019. Job security and workaholism among non-permanent workers: The moderating influences of corporate culture. Journal of Psychology in Africa 29: 443-51. [CrossRef] 
Kim, Nanhee, Yun Jin Kang, Jinsoo Choi, and Young Woo Sohn. 2020. The Crossover Effects of Supervisors' Workaholism on Subordinates' Turnover Intention: The Mediating Role of Two Types of Job Demands and Emotional Exhaustion. International Journal of Environmental Research and Public Health 17: 7742. [CrossRef]

Lanzo, Lauren, Shahnaz Aziz, and Karl Wuensch. 2016. Workaholism and incivility: stress and psychological capital's role. International Journal of Workplace Health Management 9: 165-83. [CrossRef]

Mihai, Adelina. 2017. Harta studenţilor din România: centrele universitare au atras cei mai mulţi investitori. Mai bine de 50\% dintre studenţii români învaţă în doar trei oraşe din România. Ziarul Financiar, May 19.

Molino, Monica, Arnold B. Bakker, and Chiara Ghislieri. 2016. The role of workaholism in the job demands-resources model. Anxiety, Stress \& Coping 29: 400-14.

Molino, Monica, Claudio G. Cortese, and Chiara Ghislieri. 2019. Unsustainable Working Conditions: The Association of Destructive Leadership, Use of Technology, and Workload with Workaholism and Exhaustion. Sustainability 11: 446. [CrossRef]

Muntean, Mihaela. 2016. Bridging the Gap of Education and the Requirements of the Business Environment. International Journal of Economics and Management Systems 1: 220-26.

National Statistic Institute. 2019. Average Wages. Bucharest: National Statistic Institute.

Negrila, Marius. 2019. The Influence of Professional Experience on People's Tendency Towards Workaholism. Social Sciences and Education Research Review 6: 213-21.

Nistor, Gheorghita. 2014. Workaholism: A New Challenge for Organisation Management. Procedia—Social and Behavioral Sciences 109: 295-300.

Nițu-Antonie, Renata Dana, Emőke-Szidónia Feder, and Valentin Partenie Munteanu. 2017. Macroeconomic Effects of Entrepreneurship from an International Perspective. Sustainability 9: 1159. [CrossRef]

Oncu, Marius. 2019. Scutirea de Impozit Pentru IT-iști-Ce Condiții Trebuie să Îndeplinească aceștia și firma și ce Documente sunt Necesare. Profit. Available online: https://www.profit.ro/taxe-si-consultanta/scutireade-impozit-pentru-it-isti-ce-conditii-trebuie-sa-indeplineasca-acestia-si-firma-si-ce-documente-suntnecesare-19026862 (accessed on 28 December 2019).

Özsoy, Emrach. 2019. Work and Social Life Interaction: The Link between Marriage Satisfaction and Workaholism. Paper presented at 21th BUDAPEST Int'l Conference on Law, Business, Gender \& Interdisciplinary Studies (LBGIS-19), Budapest, Hungary, July 22-24; pp. 25-29.

Popescu, Doina, Adriana Alexandru, Sebastian-Ion Ceptureanu, and Eduard-Gabriel Ceptureanu. 2018. Analysis of MSEs in ICT Domain from Bucharest-Ilfov County by using Nonaka-Takeuchi Model. Studies in Informatics and Control 27: 107-16. [CrossRef]

RaoSoft. 2020. RaoSoftware. Available online: raosoft.com/samplesize.html (accessed on 11 November 2019).

Ryan, Richard M. 1982. Control and information in the intrapersonal sphere: An extension of cognitive evaluation theory. Journal of Personality and Social Psychology 43: 450-61. [CrossRef]

Sharma, Jyoti, and Parul Sharma. 2011. Workaholism and its Correlates: A Study of Academicians. International Journal of Management and Business Research 1: 151-60.

Shin, JaeWon, and HyoungChul Shin. 2020. Impact of Job Insecurity on Hotel Workers' Workaholism and Work-Family Conflict in Korea. Int. J. Environ. Res. Public Health 17: 7783. [CrossRef] [PubMed]

Sirbu, Laurentiu. 2019. IT-iştii rămân cei mai bine plătiţi angajaţi din România. Cum continuă topul. Adevarul, September 16.

Stoeber, Joachim, and Lavinia Damian. 2016. Perfectionism in Employees: Work Engagement, Workaholism, and Burnout. In Perfectionism, Health, and Well-Being. Edited by Molnar Danielle and Sirois Fuschia. Cham: Springer, pp. 265-83.

Taris, Toon W., Ilona Van Beek, and Wilmar B. Schaufeli. 2012. Demographic and Occupational Correlates of Workaholism. Psychological Reports 110: 547-54. [CrossRef]

Tofan, Mihaela, Ana Maria Bercu, and Elena Cigu. 2015. Corporate governance framework in Romanian companies. Procedia Economics and Finance 10: 629-36. [CrossRef]

Tziner, Aharon, Lior Oren, Yaki Bar, and Gal Kadosh. 2011. CSR, Organizational Justice and Job Satisfaction: Are They Interrelated? Journal of Work and Organizational Psychology. Available online: https://papers.ssrn. com/sol3/papers.cfm?abstract_id=1885260 (accessed on 4 January 2020).

van Beek, Ilona, Qiao Hu, Wilmar B. Schaufeli, Toon W. Taris, and Bert H.J. Schreurs. 2011. For Fun, Love, or Money: What Drives Workaholic, Engaged, and Burned-Out Employees at Work? Applied Psychology 61: 30-55. [CrossRef] 
Van den Broeck, Anja, Bert Schreurs, Hans De Witte, Maarten Vansteenkiste, Filip Germeys, and Wilmar Schaufeli. 2011. Understanding Workaholics' Motivations: A Self-Determination Perspective. Applied Psychology 60: 600-21. [CrossRef]

Wiatt, Renee, and Maria Marshall. 2020. Love of Work or Love and Work? Workaholism among Small Business Owners. Paper presented at Small Business Institute 44th Annual Academic Conference, New Orleans, LA, February 27-29; New Orleans: Small Business Institute, pp. 105-20.

Yuksel, Hasan. 2014. The Concept of Workaholism As the Extreme Point in Work Engagement, Its Individual and Organizational Outcomes. Journal of Alanya Faculty of Business 6: 119-30.

Zhang, Jun, Chen Song, and Yuxuan Lan. 2020. Workaholism and Subjective Well-being: Examining a Mediation Model. Journal of Human Resource Management 8: 32-38.

Publisher's Note: MDPI stays neutral with regard to jurisdictional claims in published maps and institutional affiliations.

(C) 2020 by the authors. Licensee MDPI, Basel, Switzerland. This article is an open access article distributed under the terms and conditions of the Creative Commons Attribution (CC BY) license (http://creativecommons.org/licenses/by/4.0/). 